\title{
Pengaruh Penggunaan Model Pembelajaran Quantum Learning Terhadap Hasil Belajar Siswa Pada Materi Sistem Respirasi Pada Manusia Di SMA Swasta Kemala Bhayangkari 2 Rantauparapat, Kabupaten Labuhanbatu
}

\author{
The Influence Of Quantum Learning Model Toward Learning Outcome On Human \\ Respiration Systemin Sma Kemala Bhayangkari 2 Rantauparapat, Labuhanbatu
}

\author{
Halimah Sakdiah Boru Gultom \\ Program Studi Pendidikan Biologi, STKIP Labuhan Batu, Sumatera Utara, Indonesia \\ Koresponden: goeltom.imah@gmail.com
}

\begin{abstract}
Abstrak
Penelitian ini bertujuan untuk mengetahui pengaruh Model Pembelajaran Quantum Learning terhadap hasil belajar siswa dengan menggunakan kelas kontrol model konvensional. Populasi berupa seluruh siswa kelas XI IPA SMA Swasta Kemala Bhayangkari 2 sebanyak 4 kelas. Pengambilan sampel penelitian dengan secara Cluster sampling, data yang mendapat adalah kelas XI IPA 2 berjumlah 30 orang dan kelas XI IPA 3 berjumlah 30 orang. Tes yang digunakan sebagai instrumen penelitian adalah tes berbentuk pilihan berganda yang terdiri dari 25 soal dengan 5 option (a,b, c, d dan e). Hasil yang diperoleh pada saat Pretest dikelas eksperimen dengan nilai rata-rata 38,2 dan pada kelas kontrol dengan nilai rata-rata 32,2. Sedangkan pada Postest diperoleh dikelas Eksperimen dengan nilai rata-rata 72,66 dan pada kelas kontrol dengan nilai rata-rata 64,13. Dari pengujian Hipotesis diperoleh $t_{\text {hitung }}=3,81$ dan $t_{\text {tabel }}=2,04\left(t_{\text {hitung }}>t_{\text {tabel }}\right)$ pada $\alpha=0,05$ yang menunjukkan bahwa $H_{0}$ ditolak dan $\mathrm{H}_{\mathrm{a}}$ diterima. Hal ini menunjukkan hasil belajar siswa yang diajarkan melalui model pembelajaran Quantum Learning lebih tinggi dibandingkan hasil belajar siswa yang diajarkan dengan pembelajaran konvensional pada materi Sistem Respirasi pada Manusia dikelas XI SMA Swasta Kemala Bhayangkari 2.
\end{abstract}

Kata Kunci : Quantum learning, model pembelajaran, sistem respirasi

\begin{abstract}
This study has an objective to know the influence of Quantum Learning Model on the students' learning outcome by using a class control of conventional model. The population is all of the students in class XI Natural Sciences, Private Senior High School Kemala Bhayangkaari 2 with as many as 4 classes. The sampling is done with cluster sampling. The data collected is that in class XI Natural Science 2 there are 30 persons and in class XI Natural Science 3 there are 30 persons. The test used for the research instrument is in the form of a multiple choice consisting of 25 questions with five choice $(a, b, c, d$ and e). The result obtained during the pretest in the class of the experiment is with the average of 38.26 and in the class of control with the average of 32,2. While in the posttest it is obtained in the class of the experiment with the average of 72.66 and in the class of control with the average of 64.13. From the hypothesis testing it is obtained that $t_{\text {count }}=3.81$ and ttable $=2.04$ (tcount $>$ ttable) in $=0.05$ that shows that $\mathrm{HO}$ is rejected and $\mathrm{H}$ a is accepted. This shows that the students' learning outcome by means of Quantum Learning model is higher compared with the students' learning outcome with conventional learning on the subject matter of Human Respiratory System in class XI Private Senior High School Kemala Bhayangkari 2.
\end{abstract}

Keywords: Quantum learning,, learning model, respiration system 


\section{PENDAHULUAN}

Pendidikan adalah tahapan kegiatan yang bersifat kelembagaan yang dipergunakan untuk menyempurnakan perkembangan individu dalam menguasai pengetahuan, kebiasaan, sikap, dan sebagainya. Pendidikan merupakan proses untuk menjadikan manusia cerdas (Dalyono, 2012). Seperti yang dikemukakan Hasbullah (2009) bahwa dalam usaha mencerdaskan kehidupan bangsa, pendidikan memegang peranan penting dalam mempersiapkan sumberdaya manusia yang berkualitas.

Pembelajaran merupakan sebagai suatu proses yang dilakukan oleh individu untuk memperoleh suatu perubahan perilaku yang baru secara keseluruhan sebagai hasil dari pengalaman individu itu sendiri dalam interaksi dengan lingkungannya (Surya, 2003) dalam Kosasih dan Sumarna, 2013). Sementara itu, Daryanto (2013) mendefinisikan mengajar sebagai membimbing kegiatan belajar peserta didik sehingga ia mau belajar. Dengan demikian, aktivitas murid sangat diperlukan dalam kegiatan belajar mengajar.

Berkaitan dengan model pembelajaran, saat ini semakin banyak pengelola institusi pendidikan yang menyadari perlunya pendekatan pembelajaran yang berpusat pada pembelajar (Learner Centered). Model pembelajaran yang dapat membantu meningkatkan hasil belajar dan efektivitas siswa salah satunya adalah model pembelajaran Quantum Learning. Quantum Learning adalah salah satu model pembelajaran yang menempatkan siswa sebagai subjek pembelajaran (Student Oriented). Siswa tidak hanya sebagai penerima informasi, tetapi siswa berperan aktif dalam pembelajaran. Quantum Learning juga memberikan kesadaran bagi para pembelajar khususnya siswa tentang pentingnya belajar. Menurut DePorter dan Hernachi (2015) tumbuhnya kesadaran siswa tersebut salah satunya dikarenakan adanya AMBAK (apa manfaat bagiku). AMBAK adalah motivasi yang didapat dari pemilihan secara mental antara manfaat dan akibat-akibat suatu keputusan. Selain itu, desain suasana pembelajaran yang demokratis, saling membelajarkan dan menyenangkan dapat memberikan peluang lebih besar dalam memberdayakan potensi siswa secara optimal sehingga pembelajaran yang kurang menarik dapat diatasi.

Quantum Learning merupakan model pembelajaran yang membiasakan belajar menyenangkan (Huda, 2013). Quantum Learning merupakan salah satu model pembelajaran yang menyangkut keterampilan guru dalam merancang, mengembangkan, 
dan mengelola sistem pembelajaran sehingga guru mampu menciptakan suasana pembelajaran yang efektif, menyenangkan dan memiliki keterampilan hidup. Pelaksanaan pembelajaran quantum menimbulkan suasana nyaman, menyenangkan karena perancangan dalam pembelajaran dilakukan dengan sistematis, sehingga peserta didik akan memahami konsep. Quantum Learning merupakan suatu pendekatan pembelajaran yang memanfaatkan proses Orkestrasi dalam pembelajaran sehingga situasi dalam pembelajaran menjadi lebih menyenangkan. Tahap pembelajaran quantum learning yaitu TANDUR yang merupakan akronim dari konsep Tumbuhkan, Alami, Namai, Demonstrasikan, Ulangi dan Rayakan (DePorter dan Hernachi, 2015).

Dari hasil wawancara yang dilakukan dengan guru bidang studi Biologi yaitu bapak Abdul Rahman, S.Pd. di kelas XI SMA Swasta Kemala Bhayangkari-2 Rantauprapat diketahui bahwa ternyata nilai-nilai siswa masih belum seluruhnya mampu mencapai KKM (Kriteria Ketuntasan Minimum) yang sudah ditetapkan sekolah yaitu 70, sedangkan nilai yang diperoleh siswa yaitu 65. Hal tersebut terjadi disebabkan oleh aktivitas siswa dalam merespon pengajaran juga rendah, dimana siswa cenderung pasif selama kegiatan pembelajaran. Pembelajaran pada umumnya menggunakan metode ceramah apalagi untuk materi-materi yang sulit dan banyak soal terlalu susah dipahami siswa. Karena model pengajaran yang digunakan guru di sekolah tersebut kurang tepat dan kurang bervariasi sehingga tidak sesuai dengan proses kegiatan belajar mengajar dan siswa tidak aktif selama kegiatan belajar mengajar. Poerwanti (2008) menyatakan hasil belajar siswa dapat diklasifikasikan ke dalam tiga ranah, yaitu (1) Kognitif, pengetahuan yang mencakup kecerdasan bahasa dan kecerdasan logika-matematika, (2) Afektif, sikap dan nilai yang mencakup kecerdasan antar pribadi dan kecerdasan intra pribadi, dengan kata lain kecerdasan emosional, (3) Psikomotor, keterampilan yang mencakup kecerdasan kinestik, kecerdasan visual-spasial, dan kecerdasan musikal. Dari hasil penelitian terhadap hasil belajar siswa, dapat diketahui keberhasilan dari hasil belajar siswa.

Berdasarkan wawancara dan observasi yang dilakukan disekolah disimpulkan bahwa penggunaan model pembelajaran yang meningkatkan keterampilan guru dalam merancang, mengembangkan, dan mengelola sistem pembelajaran dan menciptakan suasana pembelajaran yang efektif perlu diterapkan. Tujuan penelitian ini adalah untuk melihat ada atau tidaknya pengaruh penggunaan model pembelajaran Quantum Learning 
terhadap hasil belajar siswa pada materi sistem respirasi pada manusia di SMA Swasta Kemala Bhayangkari-2 Rantauprapat, Kabupaten Labuhanbatu.

\section{METODE PENELITIAN}

Populasi yang digunakan dalam penelitian ini adalah seluruh kelas XI IPA SMA Swasta Kemala Bhayangkari-2 Rantauprapat yang terdiri dari empat kelas yaitu kelas XI IPA 30 orang, XI IPA 30 orang, XI IPA 30 orang dan XI IPA 40 orang dengan jumlah siswa seluruhnya 120 orang.Teknik pengambilan sampel padapenelitian ini dilakukan secara cluster sampling.Terpilih sebagai sampel adalah kelas XI IPA 2 dengan jumlah siswa 30 orang dan XI $\mathrm{IPA}_{3}$ berjumlah 30 orang sehingga jumlah populasi yang digunakan adalah 60 orang.

Jenis penelitian ini menggunakan jenis penelitian quasi eksperimen dengan pemberian perlakukan penggunaaan model pembelajaran Quantum Learning pada kelas XI IPA-2 dalam pembelajaran Biologi sub materi Sistem Respirasi pada Manusia. Untuk mengetahui hasil belajar Biologi siswa yang diperoleh dari penerapan perlakuan tersebut pada siswa diberikan test. Test yang diberikan yaitu pre-test sebelum perlakuan dan post-test setelah perlakuan. Adapun rancangan penelitian ini dapat dilihat dari Tabel 1. di bawah ini.

Tabel 1. Desain Penelitian

\begin{tabular}{cccc}
\hline Kelas & Pre-tes & Perlakuan & Post-tes \\
\hline Kelas control & $\mathrm{T}_{1}$ & $\mathrm{X}_{2}$ & $\mathrm{~T}_{2}$ \\
Eksperimen & $\mathrm{T}_{1}$ & $\mathrm{X}_{1}$ & $\mathrm{~T}_{2}$ \\
\hline
\end{tabular}

\section{Keterangan:}

$\mathrm{T}_{1}=$ Tes awal yang diberikan pada kelas kontrol dan kelas eksperimen

$\mathrm{T}_{2}=$ Tes akhir diberikan pada kelas kontrol dan kelas eksperimen

$\mathrm{X}_{1}=$ Perlakuan dengan menggunakan model pembelajaran Quantum Learning.

$\mathrm{X}_{2}=$ Perlakuan dengan menggunakan model pembelajaran konvensional.

\section{HASIL DAN PEMBAHASAN}

Berdasarkan hasil perhitungan pada data Pretest diketahui untuk kelas Eksperimen (XI $\mathrm{IPA}_{2}$ ) dengan jumlah nilai Pretest siswa sebesar 1148, rata-rata sebesar 38,26, standart deviasi sebesar 8,64, varian. Untuk lebih jelasnya hasil Pretest kelas eksperimen dengan menggunakan model pembelajaran Quantum Learning dan Pretest kelas Kontrol dengan menggunakan model pembelajaran Konvensional divisualkan pada Gambar 1. 


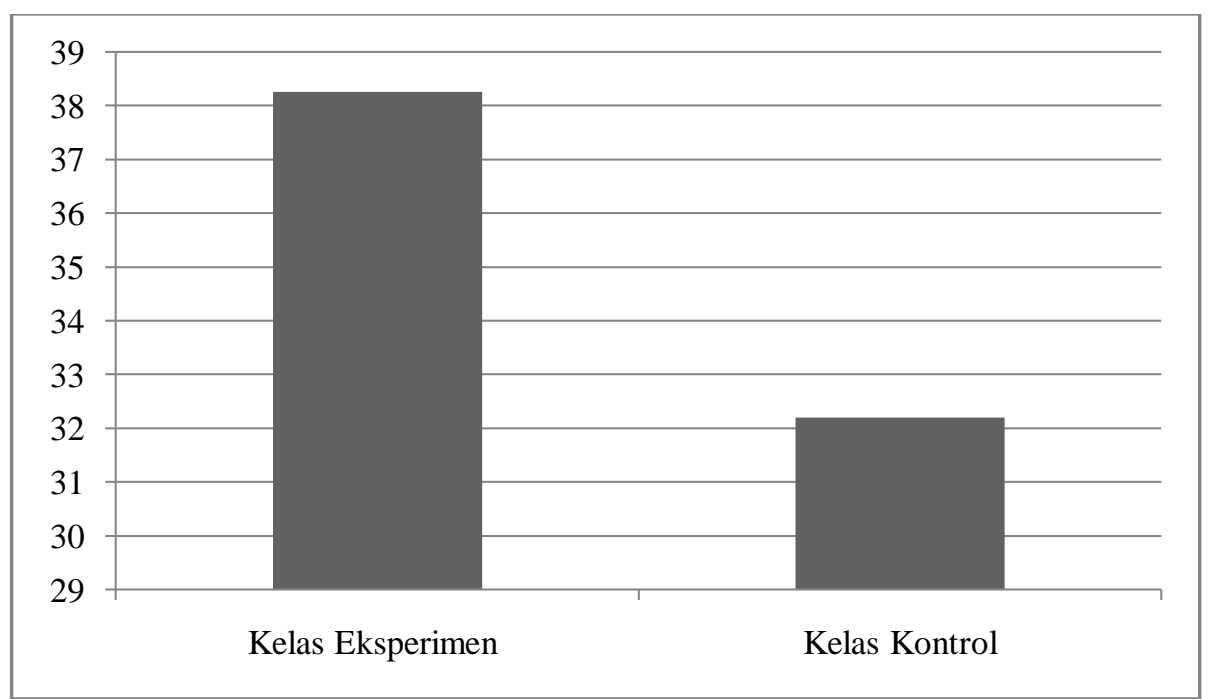

Gambar 1. Hasil Pretest kelas eksperimen (Quantum Learning) dan kelas kontrol (Konvensional).

Berdasarkan hasil perhitungan pada data Postest untuk kelas Eksperimen (XI IPA $)$ dengan jumlah nilai Postest siswa sebesar 2168, rata-rata sebesar 72,26, standart deviasi sebesar 8,33, varian sebesar 69,44 serta nilai tertinggi sebesar 88 dan nilai terendah sebesar 56. Sedangkan hasil perhitungan pada Postest untuk kelas Kontrol (XI IPA $)_{3}$ dengan jumlah nilai Postest siswa sebesar 1924, rata-rata sebesar 64,13, standart deviasi sebesar 6,76, varian sebesar 45,77 serta nilai tertinggi sebesar 76 dan nilai terendah sebesar 56. Hasil Postest kelas eksperimen dengan menggunakan model pembelajaran Quantum Learning dan Postest kelas Kontrol dengan menggunakan model pembelajaran Konvensional disajikan pada Gambar 2.

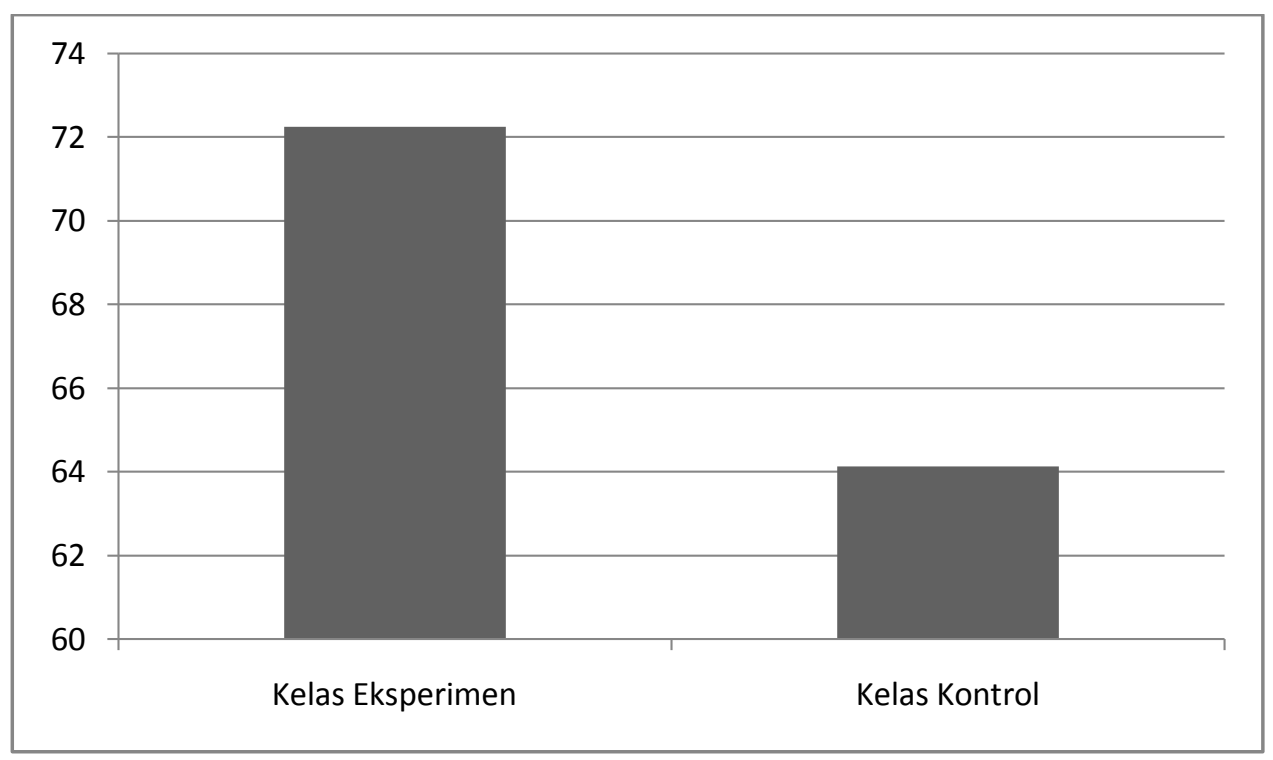

Gambar 2. Hasil Postest Kelas eksperimen (Quantum Learning) dan Postest kelas kontrol (Konvensional) 


\section{Uji Normalitas}

Untuk menguji apakah sampel berdistribusi normal atau tidak digunakan uji normalitas liliefors (Sudjana, 2014). Uji normalitas data Postest dengan menggunakan model pembelajaran Quantum Learning pada kelas Eskperimen (XI IPA $)_{2}$ diperoleh $\mathrm{L}_{\text {hitung }}<\mathrm{L}_{\text {tabel }}$ $(0,06<2,04)$ dan data Postest dengan menggunakan model Konvensional pada kelas Kontrol $\left(\mathrm{XI}\right.$ IPA $\left.\mathrm{A}_{3}\right)$ diperoleh $\mathrm{L}_{\text {hitung }}<\mathrm{L}_{\text {tabel }}(0,12<2,04)$. Dengan demikian dapat disimpulkan bahwa data Postest dengan menggunakan model pembelajaran Quantum Learning dikelas Eksperimen (XI IPA ${ }_{2}$ ) dan dengan menggunakan model Konvensional dikelas Kontrol (XI $\mathrm{IPA}_{3}$ ) berdistribusi normal.

\section{Uji Homogenitas}

Berdasarkan hasil perhitungan uji homogenitas untuk data Postest pada Kelas Eksperimen $\left(\mathrm{XI}_{\mathrm{IPA}}\right)$ dan Kelas Kontrol $\left(\mathrm{XI}\right.$ IPA $\mathrm{PA}_{3}$ ) diperoleh $\mathrm{F}_{\text {hitung }}=1,51$ dan $\mathrm{F}_{\text {tabel }}=1,86$ sehingga diperoleh $\mathrm{F}_{\text {hitung }}<_{\text {Ftabel }}(1,51<1,86)$, maka kedua sampel dinyatakan homogen.

\section{Pengujian Hipotesis}

Berdasarkan hasil uji normalitas data diketahui kedua kelas sampel berdistribusi normal dan mempunyai varians yang homogen, maka dapat dilakukan pengujian hipotesis dengan menggunakan uji t. Pada pengujian hipotesis data Pretest dengan kelas Eksperimen yang menggunakan model pembelajaran Quantum Learning dan kelas Kontrol yang menggunakan model pembelajaran Konvensional diperoleh $t_{\text {hitung }}=2,79$ dengan taraf signifikan $\alpha=0,05$ dan $\mathrm{dk}$ 30-2 sehingga diperoleh daftar $\mathrm{t}_{\mathrm{tabel}}=2,04$. Kriteria pengujian adalah terima $\mathrm{H}_{0}$ jika $\mathrm{t}_{\text {hitung }}<\mathrm{t}_{\text {tabel }}$ dan tolak $\mathrm{H}_{0}$ jika $\mathrm{t}_{\text {hitung }}>\mathrm{t}_{\text {tabel }}(2,79>2,04)$. Sedangkan data Postest dengan kelas Eksperimen yang menggunakan model pembelajaran Quantum Learning dan kelas Kontrol yang menggunakan model pembelajaran Konvensional diperoleh $t_{\text {hitung }}=$ 3,81 dan $t_{\text {tabel }}=2,04$. Kriteria pengujian adalah terima $\mathrm{H}_{0}$ jika $t_{\text {hitung }}<t_{\text {tabel }}$ dan tolak $\mathrm{H}_{0}$ jika $t_{\text {hitung }}>t_{\text {tabel }}(3,81>2,04)$. Dengan demikian $H_{0}$ ditolak dan $H_{a}$ diterima sehingga disimpulkan bahwa terdapat pengaruh terhadap hasil belajar siswa pada materi pokok sistem respirasi pada manusia.

Pelaksanaan pembelajaran Quantum Learning menimbulkan suasana nyaman, menyenangkan karena perancangan dalam pembelajaran dilakukan dengan sistematis, 
sehingga peserta didik akan memahami konsep. Dari hasil selama pelaksanaan penelitian, terlihat bahwa semangat para siswa dalam belajar lebih baik dalam proses pembelajaran dengan menggunakan model Quantum Learning yang diwujudkan pada hasil belajar yang baik. Sedangkan siswa yang diterapkanmodel pembelajaran konvensional terlihat kurang semangat dan kurang memahami materi dan diwujdukan dengan hasil belajar yang rendah. Penggunaan model pembelajaran Quantum Learning dikelas eksperimen mempunyai kelebihan yaitu sikap positif, motivasi, keterampilan belajar seumur hidup, kepercayaan diri, sukses, hasil belajar yang meningkat. Sedangkan kelemahan model pembelajaran Quantum Learning yaitu banyak menggunakan media, bagi sekolah yang tidak memiliki fasilitas yang memadai akan mengalami hambatan dalam penerapannya (DePorter dan Hernacki, 2015). Hasil penelitian ini juga sejalan dengan penelitian Hermawan (2007); Faudah (2017) yang mengatakan bahwa dengan menggunakan Quantum Learning memiliki pengaruh dalam meningkatkan hasil belajar siswa.

\section{KESIMPULAN}

Terdapat perbedaan rata-rata nilai hasil belajar yang signifikan antara penggunaan model pembelajaran Quantum Learning pada kelas Eksperimen (XI IPA $)$ dengan kelas penggunaan model pembelajaran Konvensional pada kels kontrol (XI IPA $_{3}$ di SMA Swasta Kemala Bhayangkari-2 Rantauprapat. Nilai rata-rata Postest kelas eksperimen sebesar 72,26 dengan standart deviasi 8,33. Sedangkan pada kelas kontrol (XI IPA ${ }_{3}$ ) sebesar 64,13 dengan standart deviasi 6,76 .

\section{REFERENSI}

Dalyono, 2012. Psikologi Pendidikan. Rineka Cipta. Jakarta.

Daryanto, 2013. Inovasi Pembelajaran Efektif. Yrama Widya. Bandung.

DePorter, B. dan Henacki, M., 2015. Quantum Learning. Kaifa. Bandung.

Faudah, A. Z. 2017. Pengaruh Penggunaan Model QuantumLearning Terhadap Hasil Belajar Siswa Pada Materi Pelajaran IPS Terpatu Kelas VII Di SMP Negeri 1 Air Hitam Kabupaten Lampung Barat Tahun Pembelajaran 2016/2017. Skripsi. Fakultas Keguruan Dan Ilmu Pendidikan. Universitas Lampung. Bandar Lampung. 
Hasbullah. 2009. Dasar-DasarIlmuPendidikan. Rajawali Pers. Jakarta.

Hermawan, W. 2007. Penerapan Metode Quantum Learning Untuk Meningkatkan Hasil Belajar Mata Pelajaran IPA (SAINS) Bagi Siswa Kelas V SD Negeri Kebonsari Kabupaten Temanggung. Skripsi. Fakultas Ilmu Pendidikan. Universitas Negeri Semarang. Semarang.

Huda, M, 2013. Model-Model Pengajaran dan Pembelajaran. Pustaka Pejara. Yogyakarta

Kosasih, N. dan Sumarna, D., 2013. Pembelajaran Quantum dan Optimalisasi Kecerdasan. Alfabeta. Bandung.

Poerwanti, E., 2008. AsesmenPembelajaran SD. Direktorat Jenderal Pendidikan Tinggi Departeman Pendidikan Nasional. Jakarta.

Sudjana. 2014. Penelitian Hasil Proses Belajar Mengajar. Remaja Rosdakarya. Bandung. 